\title{
JEZZYKOZNAWSTWO
}

\author{
JANA KITZLEROVÁ
}

\section{Маяковский - новатор языка? \\ Словообразовательная структура неологизмов Маяковского и их роль в современном русском языке*}

\author{
Mayakovsky, a language innovator? \\ Word-formation of Mayakovsky's neologisms, \\ their structure and role in contemporary Russian
}

\begin{abstract}
This paper deals with the word-formation of Mayakovsky's neologisms, the principles of their composition and also the objects subjected to neologization. Attention is also paid to the Nachleben of these neologisms in contemporary Russian, based on the research into the Russian National Corpus. The paper is a result of the analysis of all Mayakovsky's neologisms listed in A. Humesky's book Majakovskij and His Neologisms (1964), except for those originated by the simple connection of two words or word components. The results were compared with the most recent work dealing with Mayakovsky's neologisms, V. N. Valavin's dictionary (Word-formation of Mayakovsky. An Attempt at a Dictionary of Occasionalisms). It is argued that the main word-formation principle is that of composition (substantives and adjectives) and suffixation (verbs), that even today many neologisms show surprising vitality, and also that not all of the neologisms ascribed to Mayakovsky are indeed his authorial creations.
\end{abstract}

Keywords: neologisms, Mayakovsky, word-formation, contemporary Russian

Jana Kitzlerová, Charles University, Prague - Czech Republic, jana.kitzlerova@ff.cuni.cz, ORCID ID: https://orcid.org/0000-0001-9536-7515

Тезис о языковом новаторстве Владимира Маяковского приводится Григорием Винокуром уже в 1943 г. в книге Маяковский новатор языка (Vinokur). В этом труде говорится о поэтическом языке Маяковского в це-

\footnotetext{
* Автор выражает глубокую благодарность рецензентам за их наводящие на размышления комментарии.
} 
лом, а новаторство отмечается лишь как одна из общих характерных черт. Только двадцать лет спустя исследователи вновь обратятся к более детальному анализу языка этого автора. Так, в своей работе 1964 г. Асся Гумески (Assya Humesky) приводит 1958 неологизмов, обнаруженных в поэзии Маяковского и принадлежащих только к самостоятельным частям речи (имена существительные, прилагательные, глаголы, включая причастия, наречия, числительные). Это поражающее количество вызывает интерес, но также порождает ряд вопросов, которые можно разделить на две большие группы. Первая объединяет проблемы, относящиеся к процессу порождения неологизмов в поэзии Маяковского с учетом тематической мотивировки, в том числе: необходимость создания неологизмов в творческом процессе, какие явления прежде всего подвержены неологизации, каковы словообразовательные особенности неологизмов, какой словообразовательный принцип построения неологизмов является господствующим в его поэзии. Вторая группа затрагивает вопросы, связанные с дальнейшей судьбой неологизмов Маяковского и с авторством этих неологизмов: какие из них сохранились в языке до наших дней, все ли из приписываемых Маяковскому неологизмов действительно принадлежат этому автору.

В настоящей статье мы сосредоточимся, прежде всего, на двух интересных явлениях, которые связаны с проблематикой неологизмов рассматриваемого автора в рамках сформулированных выше проблем. Это, во-первых, господствующий словообразовательный принцип, используемый для создания новых слов, и те неочевидные причины, которые побуждали Маяковского к этому. Второй вопрос касается дальнейшей судьбы и жизнеспособности неологизмов Маяковского в современном русском языке. Для решения поставленных задач нами были рассмотрены все неологизмы, перечисленные Гумески (Humesky) в ее работе. Очевидно, что зафиксированные неологизмы имеют различный потенциал сохранения в языке, поэтому наш особый интерес вызывают те лексемы из списка Гумески, которые находятся в Национальном корпусе русского языка (NKRÂ), как наиболее устойчивые. С целью пролить свет на проблему восприятия неологизмов Маяковского в наше время, мы сопоставим результаты исходного для нас исследования Гумески не только с данными Национального корпуса русского языка, но также со Словарем окказионализмов Маяковского Валерия Валавина (Valavin). Мы рассматриваем только те неологизмы из списков Гумески и Валавина, которые присутствуют в Национальном корпусе русского языка не только в контексте произведений Маяковского, но и в других текстах. Указанный критерий оправдывает использование термина неологизм (а не окказионализм) для определения подобных слов. Отметим, что Гумески в связи с новообразованиями Маяковского употребляет термин неологизм (Humesky XI), Валавин 
же, наоборот, говорит об окказионализмах (Valavin 6). Терминологическое расхождение, по нашему мнению, на самом деле не отразилось на списках слов. Гумески и Валавин включают в свои работы все новообразования Маяковского, не обращая внимания на их единичное употребление в его поэзии или, наоборот, их дальнейшее закрепление в языке. Валавин, в отличие от Гумески, из своего списка исключает „окказиональные аббревиатурные словоформы и дериваты [...] а также аббревиатуры, созданные Маяковским”. Термин неологизм также приводится в работах других ученых, в том числе Колесникова (Kolesnikov) и Никульцевой (Nikul'ceva).

Работа Гумески стала опорной для нас по двум причинам. Во-первых, этот труд является первой по времени попыткой собрать и упорядочить неологизмы Маяковского, и для этой цели были, по словам автора, проанализированы все его стихотворения, в том числе в журнальных публикациях. Во-вторых, благодаря близости этого труда временам Маяковского (год 1964), мы предполагаем меньшую временную цезуру, а значит, и меньшую вероятность влияния времени на восприятие и оценку этих неологизмов Гумески.

Методологически подход двойного сопоставления (Гумески - Валавин - корпус) оправдывается тем, что данные национального корпуса дают информацию об употреблении рассматриваемых неологизмов в контексте всех языковых слоев и времен, а сравнение исследований Гумески с изысканиями Валавина обнаруживает замечательный сдвиг даже в области научного изучения данной темы в современности.

\section{Неологизмы Маяковского: процесс их порождения}

С точки зрения частеречной принадлежности самыми многочисленными являются группы именных (прежде всего имена существительные и прилагательные) и глагольных неологизмов; остальные классы содержат всего по несколько единиц, относительно которых мы можем с уверенностью утверждать, что они активны в языке до наших дней. Две самые крупные подгруппы - субстантивные и адъективные неологизмы - имеют несколько общих признаков в предметно-объектном плане (явления, подверженные неологизации). Совпадение проявляется частично также на уровне словообразовательных приемов, наиболее часто используемых в процессе их образования.

Какие же названия объектов подвержены неологизации? Сходство на предметном уровне проявляется прежде всего среди именных неологизмов, при помощи которых Маяковский называет, определяет или стремится более точно охарактеризовать людей, принадлежащих к недавно появившим- 
ся общественным группам и классам (совбюрократ, совмещанин, непист, колхозеи, эсэсэсэрский, эсэсэсэровский и т. д.) $)^{1}$. Несмотря на то, что между классами субстантивных и адъективных неологизмов можно найти множество общих черт в предметно-объектном плане, мы должны отметить также ряд различий: если субстантивные неологизмы, скорее, просто причисляют субъект к тому или иному общественному классу (совбюрократ, совмещанин, колхозеи), то адъективные неологизмы привносят нередко еще и дополнительную информацию, более детально характеризуют объекты неологизации (многолобый, крикогубый, громоголосый, американистый, хулиганий, большевичий и т. д.). Среди субстантивных неологизмов также можно найти слова, в которых сочетаются две формирующие идеи: принадлежность к группе и дополнительная характеристика субъекта/объекта, хотя, как правило, эту роль чаще выполняют адъективные неологизмы. В качестве примера подобных субстантивных неологизмов приведем существительное читака. Это слово не только зачисляет данное лицо в группу читателей, но и благодаря прежде всего своим грамматическим особенностям - субстантивному суффиксу, добавляет слову пренебрежительную оценку.

Что касается грамматических особенностей неологизмов Маяковского, можно констатировать, что большинство субстантивных и адъективных неологизмов являются композитами. Первая часть композитов очень часто призвана отразить новую реальность - повторяется употребление аббревиатур от прилагательного советский (сов-), или СССР (эсэсэсэр-), также от склоняемой аббревиатуры колхоз. Кроме словосложения Маяковский использует для создания новых слов четыре продуктивных суффикса, при помощи которых в русском языке традиционно образуются имена существительные: -анин, -ат, -ец и -ик. Очевидно, что большинство субстантивных неологизмов возникает в результате стремления Маяковского зачислить лица в общественные группы, возникающие в связи с появлением новой революционной и постреволюционной реальности (см. Kitzlerová 2018). Бесспорно, такие аббревиатуры субстантивного характера, как совбюрократ, совмещанин, колхозеи, непист и др., появились в связи с новым общественным строем, для описания которого Маяковскому не хватало существующих лексических единиц.

Среди описываемых субстантивных неологизмов можно выделить несколько интересных подмножеств: группу собирательных существитель-

${ }^{1}$ Следует отметить, что некоторые неологизмы (совбюрократ, колхозеи, непист) с точки зрения грамматики являются аббревиатурными новообразованиями именно из-за их первого компонента, но, учитывая их морфосинтаксические характеристики (субстантивный характер) и роль в поэзии Маяковского, мы причисляем их к группе субстантивных неологизмов. 
ных, существительных с уменьшительными суффиксами и существительных женского рода, образованных от существительных мужского рода.

На примере первой упомянутой группы собирательных существительных типа мандаринство можно еще ярче продемонстрировать интерес Маяковского к такому типу новых слов, при помощи которых он мог передать идею общности, объединения, которая вышла на первый план именно в революционные и послереволюционные времена. В качестве примера можно привести и другие неологизмы Маяковского (бароньё, капитанство, людьё, nановьё и т. д.), но так как мы ограничили нашу выборку тезисом о повторном употреблении и, по крайней мере, частичном закреплении новообразований Маяковского в современном русском языке, то остался лишь один жизнеспособный пример.

Не менее интересной является группа существительных женского рода, возникших от имен существительных мужского рода. Хотя экспрессия этих существительных различна, удивительно, что не все подобные существительные имеют ожидаемый оттенок негативной экспрессивности или отрицательной оценки. Такие субстантивные неологизмы, как ангелица, миноноcuц̧а, nacnopmuна, не обладают той негативной коннотацией, которая часто появляется при образовании существительных женского рода от существительных мужского рода ${ }^{2}$.

Самой многочисленной является группа существительных с уменьшительными суффиксами, которые Маяковский, как подтверждает контекст, употребляет исключительно в ироничной функции:

Ложий: „Готово! / На блюде! / Хлебайте сладкое с чайной ложищъь!” (Maâkovskij 1968, II: 253)

Культуришка: „футуристы / прошлое разгромили, / пустив по ветру культуришки конфетти" (Maâkovskij 1968, II: 84)

Рифмишка: ,Уселись / вдвоем / под стеклянный шар, / и первый / второму / заметил: / - Мишка, / оченно хороша - / эта / последняя / была рифмишка" (Maâkovskij 1968, II: 329)

Бытик: „Бытик / фривольный / спортом выглодан, / крымских / романов / закончили серию” (Maâkovskij 1968, II: 232); „Но часто / под этим, / покрытый плесенью, / старенький-старенький былтик" (Maâkovskij 2018: 415)

Уменьшительно-ласкательный аффикс -ик, по нашему мнению, углубляет иронию; его использование мы считаем особенно важным, хотя, к примеpy, Валавин в своем словаре данного момента не отражает (см. Valavin 84).

${ }^{2}$ Ср. такие существительные у Маяковского, как королиха, вруниха, а также широко распространенные существительные врачиха, директорша, докториа и т. д. 
По нашему мнению, этот оттенок еще ярче акцентирует ироничность высказывания, которую Маяковскому удалось достичь. Наоборот, открыто негативную экспрессивность некоторых вышеприведенных существительных усиливает суффикс -ишк(о/a), при помощи которого в русском языке традиционно возникают пейоративные существительные (Barnetová et al. 614).

Следует обратить внимание на то, что совершенно иной словообразовательный прием используется в связи с глаголами. В данном случае доминирующим предположительно является приставочный способ. Всего насчитывается пять вариантов префиксов: вbl-, pac-/paз-, o-/oб-, ис-/из-, и приставка в-, среди них самими активными можно назвать префиксы вbl-, pac-/paз-, o-/oб-. Более подробный анализ глагольных неологизмов Маяковского дает ответ на вопрос, почему он предпочитает именно вышеуказанные приставки. При помощи глаголов с префиксом $6 b l-$ и $o$-/об- акцентируется важнейший для него усилительный аспект действия: акцентируется не только полная завершенность действия, но, скорее, доведение процесса до какого-то предела или полное овладение субъекта/объекта действием (выгромить, выласкивать, вылюбить, выстонать, выплакиваться, вытолпить, обезночить, оплясать, обвыть, ошеломиться, обмозолиться и т. д.). Роль приставки рас-/раз- совсем другая: с ее помощью Маяковский обращает внимание читателя на разрушительный, преобразовательный аспект действия с масштабной полнотой (разнебеситься, развеериться ${ }^{3}$, развидеться и т. д). Одним из самых интересных примеров является глагол раздоказать, возникший от глагола доказать добавлением приставки раз-. Здесь, Маяковскому удалось в одной лексической единице соединить два совсем противоположных семантических значения 'доказать' и 'опровергнуть'4, что также подтверждается контекстом (Maâkovskij 1968, II: 50). Объединяющей чертой всех приставочных глаголов является интенсификация сообщения. Единственным, интересным примером нетипичного глагольного словообразовательного приема можно

3 У некоторых слов бросается в глаза масштабная плотность, своего рода гипертрофия представления, учитывающая лишь контекст высказывания: „у меня из-под пиджака / развеерился хвостище” (Maâkovskij 2018: 31), в котором усилительную роль играет также существительное с увеличительным суффиксом.

${ }^{4}$ Интересное толкование неологизма раздоказать предлагает рецензент статьи, восприняв глагол раздоказать как антоним к глаголу доказать. Следует сказать, что об антонимической связи между вышеупомянутыми глаголами можно говорить, лишь учитывая контекст поэзии Маяковского (см. Slovar' antonimov). Если бы мы воспринимали глагол раздоказать как антоним глагола доказать, тогда следовало бы учесть нюансы значений глаголов опровергнуть и раздоказать. В моем понимании опровергнуть можно то, что уже было доказано; наоборот, раздоказать, по-моему, относится к предшествующему процессу до момента предъявления доказательства. 
считать словосложение (сам+o+глагол), при помощи которого был образован глагол самокритиковаться.

Интересным мы считаем тот факт, что по аналогии с адъективными и некоторыми субстантивными неологизмами Маяковский употребляет также некоторые типы глаголов, как подтверждает контекст, для описания постоянного признака объекта: акварелить, иудить, хлебиться, якориться, тиниться, быстриться, длинить и т. д. Ср: „То розовым, то голубым акварелит небо хрусталик Араратика” (Maâkovskij 2018: 1070); „Видите - / небо опять иудит / пригоршнью обрызганных предательством звезд?" (Maâkovskij 2018: 962); „Хлебьтесь, поля! / Дымьтесь, фабрики!” (Maâkovskij 1968, II: 241); „О коряги / якорятся / там, / где тихая вода...”" ( Maâkovskij 2018: 692); „А ночь по комнате тинится и тинится” (Maâkovskij 2018: 953); „За каждым играющим - / красный стаж / длинит / ежедневно / времен река” (Maâkovskij 2018: 682); „Секунды быстрились и быстрились” (Maâkovskij 2018: 983).

У лексем этой глагольной группы особую усилительную функцию выполняет постфикс -cя, который еще интенсивнее фокусирует внимание на одной из семантических характеристик возвратных глаголов, а именно: на действии или состоянии, характерном для субъекта в качестве его постоянного признака; к ним относятся безобъектно-возвратные глаголы хлебиться, якориться, тиниться, юлиться, обмозолиться, быстриться.

Ранее мы сосредоточились на мотивировке (стремление именовать новые явления и отличать старое, дореволюционное, от нового, послереволюционного) и словообразовательном принципе (словосложение у субстантивных и адъективных неологизмов, приставочный способ у глаголов), порождающем новые слова у Маяковского. Анализируя адъективные неологизмы Маяковского, мы заметили тот интереснейший факт, что большая часть этих неологизмов возникла на основе метонимии (см. Kitzlerová 2018a). Метонимия как средство пополнения словарного запаса и образования поэтических эпитетов была уже неоднократно описана в научной литературе (Nekrasova; Ginzburg). Метонимию мы воспринимаем как языковую компрессию (Birih 22), лексико-семантическое явление, которое можно с точки зрения его структуры сравнить с синтаксическим эллипсисом, но без потенциального момента непонимания, который может возникать в связи с эллипсисом. Другой, важный для нас аспект метонимии, это ее характеристика как „сжатого описания" (Literaturnâ̂ ènciklopediâ 437-438). Это обусловлено тем, что в процессе возникновения метонимии внимание автора было сосредоточено на доминанте, на том, что находилось в центре поля зрения (Nekrasova). Bce вышеприведенные характеристики метонимии мы находим также у адъективных неологизмов Маяковского. 
У адъективных неологизмов Маяковского можно определить несколько объединяющих свойств.

Во-первых, семантическая близость первой части композитов. В композитах, возникших путем соединения имени числительного, наречия или местоимения и другого компонента и имеющих в своей семантике одну общую черту - множественность, часто употреблены числительные высшего разряда (сто - стовёрстый, стодомый, сторотый, миллион - миллионнопальй). Из наречий в подобных композитах употребляется единственная лексема много (многолобый, многоуличнылй), а из местоимений - одно определительное местоимение весь (всехсветный, всемирнейший), которое также содержит в своей семантике количественный аспект. Более подробный анализ неологизмов с компонентом весь указывает, что в их семантике доминирует, скорее, оттенок целостности. Учитывая также их контекст, следует уточнить нашу предпосылку - основу данных неологизмов надо искать в комплексности, единодушии, всевластии, которые Маяковский, с их помощью, акцентирует.

Во-вторых, сосредоточенность автора на доминанте описываемого объекта, как сжатого описания, проявляется часто в композитах, возникших в результате соединения двух существительных с присоединением окончания прилагательного или прилагательного с существительным с присоединением окончания прилагательного. В качестве составных частей подобного рода неологизмов очень часто фигурируют элементы тела человека, которые традиционно привлекают внимание при описании лица и фигуры человека (живот - потножсивотый, губа - крикогубый, грудь - стальногрудый), наряду с выразительными действиями человека (крик - крикогубый, голос - громоголосый).

В-третьих, безусловно, качественная оценка, присутствующая в семантике слова. В данном случае имеются в виду композиты, образованные при помощи прилагательного и существительного с добавлением адъективной флексии. Повторно употреблены качественные прилагательные, в семантике которых априори присутствует аспект качественности или ценности (золотой - златолобый, семантика этого слова связана с представлением о благородном металле).

Что касается большинства других адъективных неологизмов, также можно с уверенностью констатировать, что в их структуре проявляется момент метонимической компрессии как результат акцентирования доминанты в процессе описания данного объекта, о чем свидетельствует часто также их синтаксическое окружение. На примере прилагательных старомозгий, молоткастый, серпастый, стоугольный, стодомый, стоводный, учитывая также контекст их употребления, можно убедительно продемонстрировать процесс их образования метонимическим путем: 
Старомозгий: тот, у кого старый мозг („Бойтесь пушкинистов. / Старомозгий Плюшкин, / перышко держа, / полезет с перержавленным" Maâkovskij 1968, IV: 51)

Молоткастый и серпастый: символы на паспорте, привлекающие внимание (,я был бы / исхлестан и распят / за то, что в руках у меня / молоткастый, / серпастый / советский паспорт" - Maâkovskij 1968, VIII: 67)

Стоугольный: высокая производительность - главный и ожидаемый атрибут шахты („и взроет / недра / шахтою / стоугольный / «Гигант»” Maâkovskij 1968, VIII: 127)

Стодомый: плотность застройки, как в библейском Содоме („Где бор был - площадь стодомым содомом" - Maâkovskij 1968, I: 164)

Стоводный: обилие воды в реке („Стоводная удаль безудержной Волги” - Maâkovskij 1968, V: 177)

\section{Неологизмы Маяковского: прошлое и настоящее}

Как уже упоминалось выше, неологизмы, которые приводит в своем труде Гумески (Humesky 1964), мы сопоставили с данными Национального корпуса русского языка и словаря неологизмов Маяковского Валавина (Valavin 2010), чтобы, во-первых, определить жизнеспособность этих неологизмов в современном русском языке, и, во-вторых, подтвердить/опровергнуть их авторство. В корпусе были исследованы все неологизмы Маяковского, относящиеся к самостоятельным частям речи, исключая те, которые мы не считаем неологизмами, так как речь идет только о формально, графически соединенных словах или частях слов, соединенных через дефис. Положительным мы считаем такой результат, когда неологизм употреблен в контексте, не связанном с именем Маяковского, т. е. были исключены явные цитаты и ссылки на поэзию Маяковского и т. д. Проведенное нами сравнение дало несколько интересных результатов.

Что касается проблемы использования неологизмов Маяковского в современном русском языке, исследование корпуса подтверждает предположение, что некоторые из неологизмов Маяковского до сих пор активно употребляются носителями языка, хотя по сравнению с огромным количеством неологизмов, упоминаемых в работе Гумески (1958 лексем), до настоящего времени в языке сохранились лишь немногие. Итак, исследование, проведенное на материале Национального корпуса русского языка, свидетельствует об активном употреблении 76 имен существительных, 75 имен прилагательных и 53 глаголов (см. приложения 1, 2, 3); только небольшое число неологизмов упоминается в корпусе в связи с именем 
Маяковского (в ссылках, цитатах и т. д.). Отдельно следует отметить, что большинство неологизмов Маяковского, используемых в современном русском языке, сохранило свою семантику и часто даже стилистическую окраску. Из всего числа его неологизмов лишь два адъективных слова приобрели новое семантическое насыщение: златолобый (в современном русском языке употребляется в области орнитологии), и люлечный (имеет техническое значение). Наоборот, интересным примером стилистического сдвига является существительное манифестик с ярко выраженным ироничным оттенком. И хотя суффикс -ик является продуктивным в разговорном языке, мы считаем, с учетом контекста, что у Маяковского он яркий пример неологизации и стилистического сдвига, приводящего к иронии. Корпус свидетельствует об употреблении этого слова и до Маяковского, но только как перевод с французского языка выражения le petit manifeste, не имеющего никакой экспрессивной окраски. Не менее интересным является судьба прилагательного столищый, в связи с которым можно говорить о семантической неологизации или семантическом сдвиге. К данному прилагательному словари (Valavin 520) приводят синоним столикий, толкование которого дает другую характеристику субъекта/объекта: многообразность. Этот семантический оттенок, как показывает контекст: „Губ не хватит улыбке столицей” (Maâkovskij 2018: 996), Маяковский не учитывает. По нашему мнению, первично акцентируется множество, многообразность же мы считаем вторичным, возможно, дополнительным признаком.

Анализ языкового материала в корпусе русского языка также обнаружил интересный факт, что некоторые из неологизмов, чье авторство приписывалось Маяковскому, на самом деле были им заимствованы у его товарищей по цеху (например, у Игоря Северянина, и - что не менее удивительно у поэтов совершенно другого поэтического течения: Сергея Есенина, Андрея Белого, Марины Цветаевой). Одной из возможных причин этого может быть то, что некоторые неологизмы, которые мы считаем заимствованиями в поэзии Маяковского, возникали в непосредственной временной близости от творений нашего автора, так что не всегда оправдано называть их заимствованиями. На этот факт обращает внимание уже Михаил Гаспаров: „Формы типа раскалонней встречались и у символистов, форма златоустейший, предполагающая превращение относительного прилагательного в качественное, более необычная и специфична для Маяковского" (Gasparov 368). Однако 37 неологизмов (10 имен существительных, 10 имен прилагательных и 18 глаголов), которые Гумески приписала перу Маяковского, были ранее употреблены в произведениях других авторов: шесть неологизмов можно найти в творчестве Андрея Белого (ангеленок, бестоварье, облаковый, блоший, выкруглить, прочеловать), четыре - в поэзии Сергея Есенина (облачье, 
огнепёрый, муший и писнуть), четыре - у Игоря Северянина (мореть, лавить, одиночить, весениться) и три - в произведениях Марины Цветаевой (грачий, всвистать, взмахать) (см. Приложение 4).

Не менее интересна история глагола высинить, который был также приписан Маяковскому в работе Асси Гумески. Этот глагол, как указывает русский корпус, встречается уже в Российской грамматике Михаила Васильевича Ломоносова 1755 г., и то, что данный глагол был причислен к списку неологизмов Маяковского по ошибке, также подтверждает словарь Валавина (Valavin 86-128). Почему тогда Гумески считает этот глагол неологизмом Маяковского? Одна из возможных гипотез - временное устранение этого глагола из языка, о чем также свидетельствует корпус: после грамматики Ломоносова это слово вновь вошло в обиход только в 20-х годах XX века.

Вышеприведенные данные, по нашему мнению, если уж и не полностью проливают свет на те источники, которые вдохновляли Маяковского, то хотя бы в некотором роде очерчивают его читательский интерес и подтверждают, что он был хорошо знаком с творчеством широкого круга авторов. Этот факт также может быть потенциально интересен для литературоведов и историков языка.

Другой интересный результат дает сопоставление списка Гумески со словарем Валавина. Мы сначала сосредоточились на лексических единицах, заимствование которых Маяковским было подтверждено раньше: из 37 заимствований, по данным корпуса, лишь 10 отсутствует в словаре. Остальные же 27 Валавин фиксирует как окказионализмы Маяковского.

Сравнение этих двух трудов (Гумески и Валавина) открывает и другие интересные факты. Словарь Валавина включает несколько слов, которые не являются новообразованиями Маяковского, наоборот, некоторые неологизмы, убедительно принадлежащие перу Маяковского, словарь не фиксирует: 16 имен существительных, 7 имен прилагательных и 9 глаголов в словарь не вошло. Хотя, по словам автора, им были исключены из рассмотрения некоторые лексические единицы, а именно „оказиональные аббревиатурные словоформы и дериваты [...], а также аббревиатуры” (Valavin 19), - возникает вопрос, почему именно эти тридцать два слова, среди которых находим даже единственный кодифицированный неологизм Маяковского - существительное бескультурье - были пропущены?

Ответ предлагает сам список исключенных слов: алчь, аэростанщия, бескультурье, бровинка, вкуснота, гражданчик, колхозеи, лачок, непист, орло, переносье, радиомитинг, слоновость, читака, электрощетка, языкотвореи, бригадовый, крабий, краснозвездный, носастый, пылеватый, ручьевой, ущельный, эсэсэсэровский, быстриться, воскрыть, выплаки- 
ваться, вышептать, колокольнуть, нажрать, обмозолиться, сбороть, юлиться. Из него вытекает, что многие из них настолько распространены в языке, что не бросаются в глаза как неологизмы. Даже если устраним те, которые не соответствуют правилам словаря (колхозец, непист, эсэсэсэровский), остается ряд лексических единиц, чье неологическое происхождение носитель языка, видимо, уже не осознает, и поэтому они остались не замеченными автором. Данные единицы полностью соответствуют законам грамматического строя русского языка (прежде всего словообразовательным принципам) и являются совершенно готовыми к потенциальному закреплению в языке.

\section{Маяковский новатор языка?}

С опорой на книгу Гумески нами было произведено исследование неологизмов Маяковского, принадлежащих к самостоятельным частям речи. Результаты были сопоставлены с материалами Национального корпуса русского языка и со списком окказионализмов, приводимым Валавином. Наши разыскания помогли найти ответы на сформулированные выше вопросы и, более того, обнаружили два дополнительных факта, на которых нам хотелось бы остановиться более подробно.

Как уже было сказано раньше, доминирующими словообразовательными принципами, использованными Маяковским для создания новых слов, являются словосложение для имен и приставочный принцип для глаголов. Оба эти приема полностью соответствуют законам грамматического строя русского языка. Но помимо этого можно также выделить необычный прием, точнее мотивировку, которая играла крупнейшую роль в процессе создания адъективных неологизмов, - метонимию. Именно метонимическое сжатие помогало Маяковскому создавать адъективные неологизмы, которые вмещают в себя и конденсируют как минимум две языковые единицы. Мы полагаем, что именно это сжатие помогало Маяковскому выражаться быстро, экономно и отрывисто, чем и отличается стиль нашего автора; по его собственным словам: „Нервная жизнь городов требует слов быстрых, экономных, отрывистых" (цит. по: Markov 157).

Сравнение неологизмов Маяковского, приводимых Гумески, со словарем Валавина обнаруживает, что жизнеспособность некоторых неологизмов нашего автора настолько высока, что некоторые из них не воспринимаются как авторские конструкты, о чем свидетельствует словарь Валавина, в котором было пропущено 32 неологизма. 
Среди причин, побудивших Маяковского образовывать новые слова, можно выделить прежде всего необходимость именовать объекты новой реальности, а также его стремление более емко и точно характеризовать субъекты, объекты и явления, тесным образом связанные с революционными и постреволюционными событиями, чтобы более четко отделить дореволюционную действительность от нового времени, о чем свидетельствует ряд основ, которые послужили фундаментом для образования композитов (сов-, CСР-, неп-, колхоз). Для достижения этих целей автор широко использовал неологизмы из числа имен существительных и прилагательных. Глаголы же, напротив, служили поэту, скорее, для усиления экспрессивной окраски (именно усилительные префиксы $b b l-$ и $о$-/об-), а также как средство приписывания постоянных признаков субъектам, объектам, явлениям. Как замечает Гаспаров, реализовать замысел отражения пластичности и яркости высказывания Маяковскому помогали, не только неологизмы, но также и морфологические средства, например, падежные формы: „Кажется, что слово в творительном падеже представлялось Маяковскому выпуклее, чем в именительном или винительном [...]. Из других падежей лишь однажды, но очень ярко в этой функции выступает винительный с предлогом [...]” (Gasparov 375).

Многие из неологизмов Маяковского показывают удивительную жизнеспособность, сохраняясь в языке до наших дней. Из них самыми активными являются те, которым удалось занять пустующее семантико-стилистическое место в синонимическом ряду ${ }^{5}$, например, существительное бескультурье, которое было даже кодифицировано. Если мы сопоставим этот неологизм с синонимами его же ряда, то становится очевидным, что ни один из них не может соперничать с этим словом ни в области семантической, ни в области стилистической синонимии, ср.: азиатчина, бескультурье, варварство, дикарство, малосознательность, некультурность, несознательность, отсталость (Slovar'sinonimov).

Проведенное исследование показало, что, несмотря на то, что Маяковский является автором не всех упомянутых предыдущими исследователями неологизмов, его, бесспорно, можно назвать новатором языка, одним из самых ярких поэтов своей эпохи.

\footnotetext{
5 Иную гипотезу предлагает рецензент статьи: в языке до наших дней сохранились слова, построенные на основе привычных словообразовательных схем. Эта гипотеза при всей своей правдоподобности не принимает во внимание того факта, что некоторые совсем традиционно построенные слова постепенно утратили свое отражение в реальности с исчезновением предметов или явлений.
} 
Приложение 1. Имена существительные

\begin{tabular}{|c|c|c|}
\hline Имена существительные & В списке Гумески & В словаре Валавина \\
\hline \multirow{10}{*}{$\begin{array}{l}\text { Суш. женского рода от сущ. рода } \\
\text { мужского }\end{array}$} & ангелица & $\mathrm{X}$ \\
\hline & вруниха & $\mathrm{X}$ \\
\hline & калекша & $\mathrm{X}$ \\
\hline & королиха & $\mathrm{X}$ \\
\hline & леева & $\mathrm{X}$ \\
\hline & лечёба & $\mathrm{X}$ \\
\hline & лохматина & $\mathrm{X}$ \\
\hline & миноносица & $\mathrm{X}$ \\
\hline & паспортина & $\mathrm{X}$ \\
\hline & пилсудчина & $\mathrm{X}$ \\
\hline \multirow[t]{9}{*}{ Принадлежность к группе лии } & галёрочник & $\mathrm{X}$ \\
\hline & голгофник & $\mathrm{X}$ \\
\hline & драмщик & $X$ \\
\hline & колхозец & \\
\hline & непист & \\
\hline & совбюрократ & $\mathrm{X}$ \\
\hline & совмещанин & $\mathrm{X}$ \\
\hline & таборник & $\mathrm{X}$ \\
\hline & читака & \\
\hline \multirow{4}{*}{$\begin{array}{l}\text { Характеристика субъекта/объ- } \\
\text { екта }\end{array}$} & библеец & $\mathrm{X}$ \\
\hline & мандаринство & $\mathrm{X}$ \\
\hline & читака & \\
\hline & языкотворец & \\
\hline \multirow[t]{7}{*}{ Собирательные сущ. } & безножье & $\mathrm{X}$ \\
\hline & бескультурье & \\
\hline & блестенье & $\mathrm{X}$ \\
\hline & громадьё & $\mathrm{X}$ \\
\hline & дамьё & $\mathrm{X}$ \\
\hline & мандаринство & $\mathrm{X}$ \\
\hline & тщенье & $\mathrm{X}$ \\
\hline \multirow{8}{*}{$\begin{array}{l}\text { С уменьшительнылми и/или } \\
\text { уменьиительно-ласкательныли } \\
\text { суффиксами }\end{array}$} & бровинка & \\
\hline & бытик & $\mathrm{X}$ \\
\hline & версийка & $\mathrm{X}$ \\
\hline & гражданинчик & \\
\hline & зверик & $\mathrm{X}$ \\
\hline & культуришка & $\mathrm{X}$ \\
\hline & ложица & $\mathrm{X}$ \\
\hline & манифестик & $\mathrm{X}$ \\
\hline
\end{tabular}




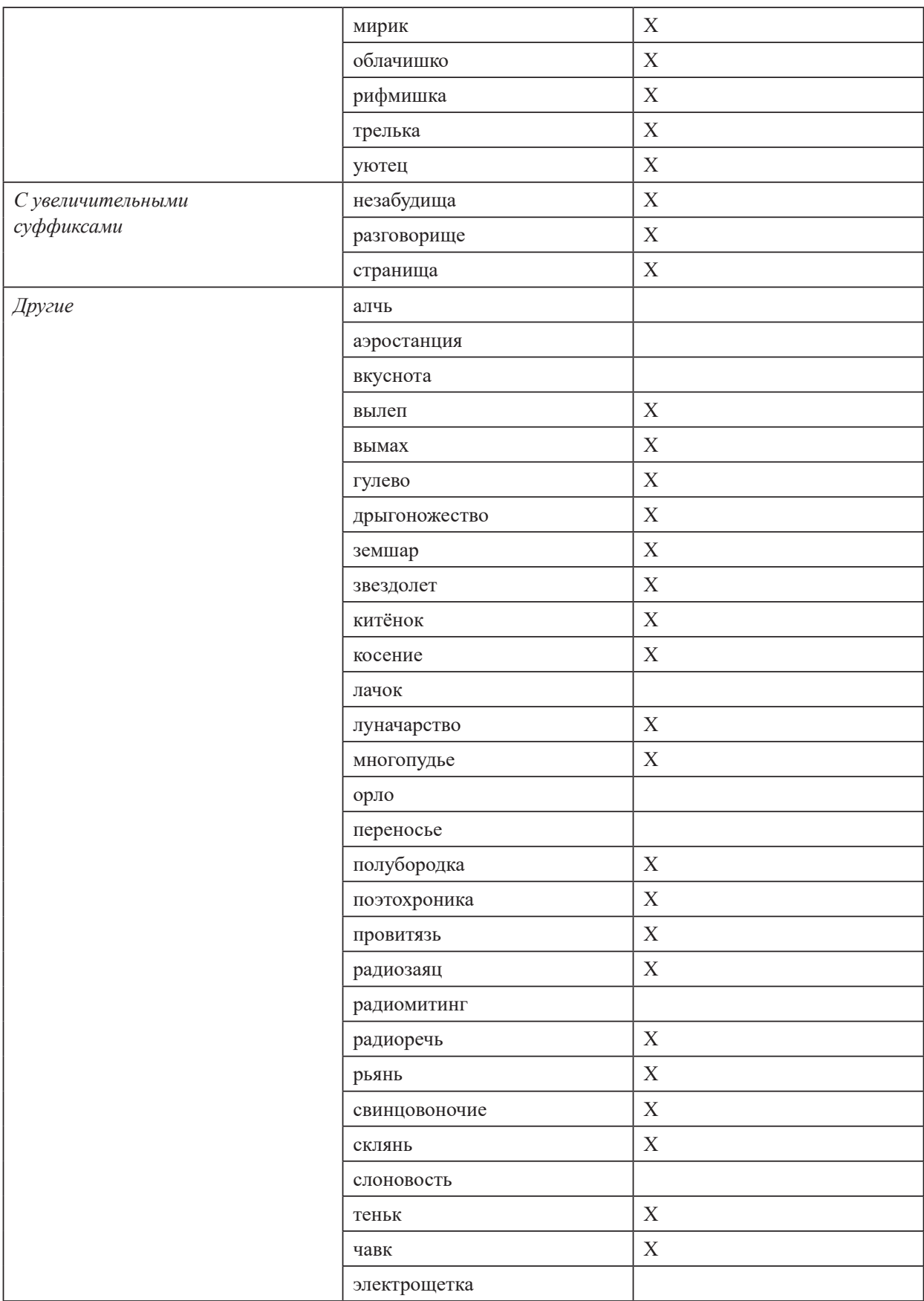


Приложение 2. Имена прилагательные

\begin{tabular}{|c|c|c|}
\hline Имена прилагательные & В списке Гумески & В словаре Валавина \\
\hline \multirow[t]{2}{*}{ С новой семантикой } & златолобый & $\mathrm{X}$ \\
\hline & люлечный & $\mathrm{X}$ \\
\hline \multirow{14}{*}{$\begin{array}{l}\text { Принадлежность к группе лии + } \\
\text { характеристика субъекта/объекта }\end{array}$} & американистый & $\mathrm{X}$ \\
\hline & большевичий & $\mathrm{X}$ \\
\hline & зверий & $\mathrm{X}$ \\
\hline & зверячий & $\mathrm{X}$ \\
\hline & крабий & \\
\hline & крысячий & $\mathrm{X}$ \\
\hline & лососиний & $\mathrm{X}$ \\
\hline & слонячий & $\mathrm{X}$ \\
\hline & тигрячий & $\mathrm{X}$ \\
\hline & хламовый & $\mathrm{X}$ \\
\hline & хулиганий & $\mathrm{X}$ \\
\hline & эсэсэсэровский & \\
\hline & эсэсэсэрский & $\mathrm{X}$ \\
\hline & ящерий & $\mathrm{X}$ \\
\hline \multirow[t]{18}{*}{ Другие } & аврорский & $\mathrm{X}$ \\
\hline & автомобилий & $\mathrm{X}$ \\
\hline & ампиристый & $\mathrm{X}$ \\
\hline & ангелий & $\mathrm{X}$ \\
\hline & аэроплановый & $\begin{array}{l}\text { X (в притяжательной форме: } \\
\text { аэропланов) }\end{array}$ \\
\hline & бабистый & $\mathrm{X}$ \\
\hline & болоночий & $\mathrm{X}$ \\
\hline & бригадовый & $\begin{array}{l}\text { Х (в притяжательной форме: } \\
\text { бригадов) }\end{array}$ \\
\hline & верненький & $\mathrm{X}$ \\
\hline & водний & $\mathrm{X}$ \\
\hline & всемирнейший & $\mathrm{X}$ \\
\hline & всехсветный & $\mathrm{X}$ \\
\hline & гейнеобразный & $\begin{array}{l}\text { Х (приводится только форма } \\
\text { ср. рода) }\end{array}$ \\
\hline & громоголосый & $\mathrm{X}$ \\
\hline & двухметроворостый & $\mathrm{X}$ \\
\hline & декабрый & $\mathrm{X}$ \\
\hline & домовий & $\mathrm{X}$ \\
\hline & иголий & $X$ \\
\hline
\end{tabular}




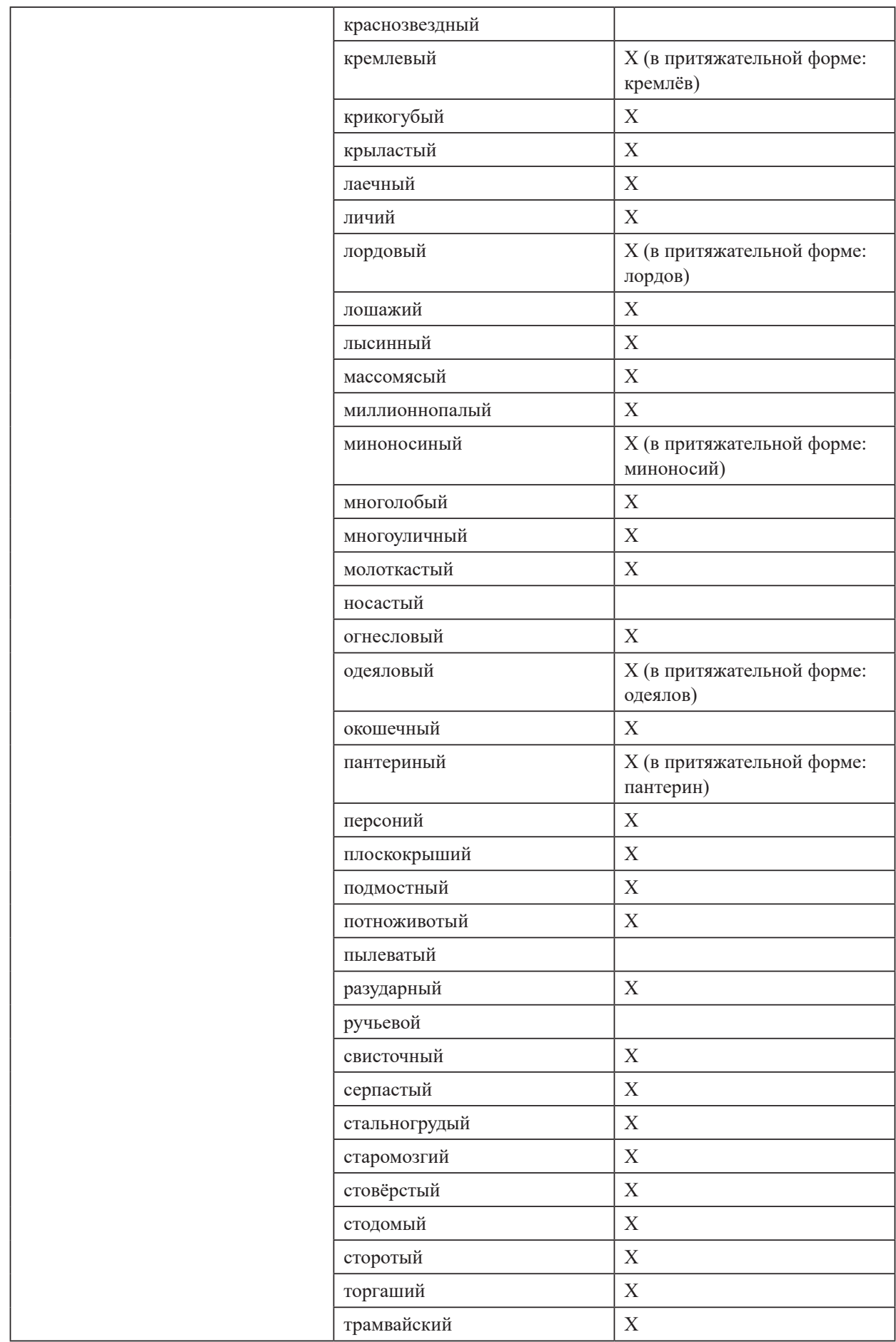




\begin{tabular}{|l|l|l|}
\hline \multirow{4}{*}{} & удушливогазный & $\mathrm{X}$ \\
\cline { 2 - 3 } & ущельный & \\
\hline & флажий & $\mathrm{X}$ \\
\hline & хламовый & $\mathrm{X}$ \\
\hline & хулиганий & $\mathrm{X}$ \\
\hline & штыкастый & $\mathrm{X}$ \\
\hline & эполетовый & $\begin{array}{l}\text { Х (в притяжательной форме: } \\
\text { эполетов) }\end{array}$ \\
\hline
\end{tabular}

Приложение 3. Глаголы

\begin{tabular}{|c|c|c|}
\hline Глаголы & В списке Гумески & В словаре Валавина \\
\hline \multirow[t]{8}{*}{ Признак (постоянный) } & акварелить & $\mathrm{X}$ \\
\hline & быстриться & \\
\hline & длинить & $\mathrm{X}$ \\
\hline & иудить & $\mathrm{X}$ \\
\hline & тиниться & $\mathrm{X}$ \\
\hline & хлебиться & $\mathrm{X}$ \\
\hline & юлиться & \\
\hline & якориться & $\mathrm{X}$ \\
\hline \multirow[t]{10}{*}{ С префиксом вы- } & выгромить & $\mathrm{X}$ \\
\hline & выласкать & $\mathrm{X}$ \\
\hline & выласкивать & $\mathrm{X}$ \\
\hline & вылюбить & $\mathrm{X}$ \\
\hline & вымычать & $X$ \\
\hline & выплакиваться & \\
\hline & выстонать & $X$ \\
\hline & вытолпить & $\mathrm{X}$ \\
\hline & вышептать & \\
\hline & выщетиниться & $X$ \\
\hline \multirow[t]{6}{*}{ С префиксом рас-/раз- } & развеериться & $\mathrm{X}$ \\
\hline & развидеться & $\mathrm{X}$ \\
\hline & раздождиться & $\mathrm{X}$ \\
\hline & раздоказать & $\mathrm{X}$ \\
\hline & разнебеситься & $\mathrm{X}$ \\
\hline & раскиселиться & $\mathrm{X}$ \\
\hline \multirow[t]{4}{*}{ С префиксом о-/об- } & обвыть & $\mathrm{X}$ \\
\hline & обезночеть & $\mathrm{X}$ \\
\hline & обмозолиться & \\
\hline & овазиться & $\mathrm{X}$ \\
\hline
\end{tabular}




\begin{tabular}{|c|c|c|}
\hline & овенчаться & $\mathrm{X}$ \\
\hline & оглазеть & $\mathrm{X}$ \\
\hline & оплясать & $\mathrm{X}$ \\
\hline \multirow[t]{3}{*}{ С префиксом из-/ис- } & издымиться & $\mathrm{X}$ \\
\hline & изъздеваться & $\mathrm{X}$ \\
\hline & испешеходить & $\mathrm{X}$ \\
\hline \multirow[t]{3}{*}{ С префиксом в-/во- } & воскрыть & \\
\hline & впластаться & $\mathrm{X}$ \\
\hline & вцеловать & $\mathrm{X}$ \\
\hline \multirow[t]{14}{*}{ Другие } & зальдиться & $\mathrm{X}$ \\
\hline & заразмножаться & $\mathrm{X}$ \\
\hline & карабкать & $\mathrm{X}$ \\
\hline & колокольнуть & \\
\hline & нажрать & \\
\hline & ошеломиться & $\mathrm{X}$ \\
\hline & плесниться & $\mathrm{X}$ \\
\hline & ржануть & $\mathrm{X}$ \\
\hline & самокритиковаться & $\mathrm{X}$ \\
\hline & сбороть & \\
\hline & сливеть & $\mathrm{X}$ \\
\hline & сшататься & $\mathrm{X}$ \\
\hline & штрафнуть & $\mathrm{X}$ \\
\hline & юбилеить & $\mathrm{X}$ \\
\hline
\end{tabular}

Приложение 4. Заимствования Маяковского

\begin{tabular}{|l|l|l|}
\hline \multirow{4}{*}{ Автор } & \multicolumn{1}{|c|}{$\begin{array}{c}\text { Заимствования } \\
\text { Маяковского }\end{array}$} & \multicolumn{1}{|c|}{ В словаре Валавина } \\
\hline \multirow{5}{*}{ Аельй } & ангелёнок & $\mathrm{X}$ \\
\hline & бестоварье & \\
\hline & блоший & $\mathrm{X}$ \\
\hline & выкруглить & \\
\hline & облаковый & \\
\hline & процеловать & $\mathrm{X}$ \\
\hline \multirow{5}{*}{ Сергей Есенин } & муший & $\mathrm{X}$ \\
\hline & облачье & $\mathrm{X}$ \\
\hline & огнепёрый & $\mathrm{X}$ \\
\hline & писнуть & \\
\hline \multirow{5}{*}{ Игорь Северянин } & весениться & $\mathrm{X}$ \\
\hline & лавить & $\mathrm{X}$ \\
\hline
\end{tabular}




\begin{tabular}{|c|c|c|}
\hline & мореть & $\mathrm{X}$ \\
\hline & одиночить & $\mathrm{X}$ \\
\hline Марина Цветаева & взмахать & \\
\hline & всвистать & $\mathrm{X}$ \\
\hline & грачий & $\mathrm{X}$ \\
\hline Другие & березиный (Сергей Бобров) & $\begin{array}{l}\text { X (в притяжательной форме: } \\
\text { березин) }\end{array}$ \\
\hline & вражище (Михаил Пришвин) & $\mathrm{X}$ \\
\hline & $\begin{array}{l}\text { высинить (Михаил } \\
\text { Ломоносов) }\end{array}$ & \\
\hline & $\begin{array}{l}\text { звездность (Константин } \\
\text { Бальмонт) }\end{array}$ & $\mathrm{X}$ \\
\hline & $\begin{array}{l}\text { изработаться (Максим } \\
\text { Горький) }\end{array}$ & \\
\hline & $\begin{array}{l}\text { искрить (Всеволод } \\
\text { Крестовский) }\end{array}$ & \\
\hline & кафейный (Павел Анненков) & $\mathrm{X}$ \\
\hline & $\begin{array}{l}\text { крокодилий (Николай } \\
\text { Гумилев) }\end{array}$ & \\
\hline & $\begin{array}{l}\text { нынчесть (Константин } \\
\text { Олимпов) }\end{array}$ & $\mathrm{X}$ \\
\hline & $\begin{array}{l}\text { обезумиться (Василий } \\
\text { Жуковский) }\end{array}$ & $\mathrm{X}$ \\
\hline & орнуть (Алексей Ремизов) & $\mathrm{X}$ \\
\hline & пещрить (Антон Чехов) & $\mathrm{X}$ \\
\hline & прошагивать (Леонид Леонов) & $\mathrm{X}$ \\
\hline & развихрить (Николай Клюев) & $\mathrm{X}$ \\
\hline & $\begin{array}{l}\text { рококовый (Алексей } \\
\text { Крученых) }\end{array}$ & $\mathrm{X}$ \\
\hline & ростик (Евгений Замятин) & $\mathrm{X}$ \\
\hline & сеево (Николай Асеев) & \\
\hline & содрогать (Давид Бурлюк) & \\
\hline & французистый (Антон Чехов) & $\mathrm{X}$ \\
\hline & хвоститься (Зинаида Гиппиус) & $\mathrm{X}$ \\
\hline & царище (Николай Клюев) & $\mathrm{X}$ \\
\hline & $\begin{array}{l}\text { эсдечество (Михаил } \\
\text { Пришвин) }\end{array}$ & $\mathrm{X}$ \\
\hline
\end{tabular}




\section{Библиография}

Barnetová, Vilma et al. Russkâ̂ grammatika. Praha, Československá akademie věd, 1979.

Birih, Aleksandr. Metonimiâ v sovremennom russkom âzyke. Semantičeskij i grammatičeskij aspekty. München, Otto Sagner, 1995.

Gasparov, Mihail. „Vladimir Maâkovskij”. Očerki istorii âzyka russkoj poèzii XX veka: Opyty opisaniâ idiostilej. Red. Viktor Grigor'ev, Elena Krasil'nikova. Moskva, Nasledie, 1995, s. 363-395.

Ginzburg, Efim. Konstrukcii polisemii v russkom âzyke. Taksonomiâ i metonimiâ. Moskva, Nauka, 1985.

Humesky, Assya. Majakovskij and His Neologisms. New York, Rausen, 1964.

Kiclerova, Âna. „Ad”ektivnye neologizmy Maâkovskogo: struktura, principy obrazovaniâ i ih ispol'zovanie v sovremennom russkom âzyke". Izvestiâ RAN. Seriâ literatury i âzyka, 77, 6, 2018, s. 43-53.

Kitzlerová, Jana. „Majakovskij a «byt»: analýza vybraných adjektivních neologismů a jejich užití v současné ruštině". Studia Slavica, 21/2, 2017, s. 75-85.

Kolesnikov, Nikolaj. Slovar' neologizmov V.V. Maâkovskogo. Tbilisi, Izdatel'stvo Tbilisskogo universiteta, 1991.

Literaturnaâ ènciklopediâ. Moskva, L.D. Frenkel', 1925.

Maâkovskij, Vladimir. Bol’šoe sobranie stihotvorenij i poèm v odnom tome. Moskva, Èksmo, 2018.

Maâkovskij, Vladimir. Sobranie sočinenij v vos'mi tomah. T. II, IV, VIII. Moskva, Pravda, 1968.

Markov, Vladimir. Istoriâ russkogo futurizma. Sankt-Peterburg, Aletejâ, 2000.

Nekrasova, Elena. „Metonimičeskij perenos v svâzi s nekotorymi problemami lingvističeskoj poètiki”. Slovo v russkoj sovetskoj poèzii. Red. Viktor Grigor'ev. Moskva, Nauka, 1975, s. 111-131.

Nikul'ceva, Viktoriâ. „Identičnye neologizmy v poètičeskom âzyke Vladimira Maâkovskogo i Sergeâ Esenina”. Russkaâ reč', 1-2, 2010, s. 32-39.

NKRÂ - Nacional'nyj korpus russkogo âzyka. Web. 08.08.2020. http://ruscorpora.ru/index.html.

Slovar' antonimov. Web. 09.11. 2020. http://gramota.ru/slovari/info/lv/.

Slovar' sinonimov. Web. 12.08.2020. https://словарь-синонимов.pф/.

Valavin, Valerij. Slovotvorčestvo Maâkovskogo. Opyt slovarâ okkazionalizmov. Moskva, Izdatel'skij centr „Azbukovnik”, 2010.

Vinokur, Grigorij. Maâkovskij novator âzyka. Moskva, KomKniga, 1943. 